\title{
Review
}

\section{Pleurotus Genus as a Potential Ingredient for Meat Products}

\author{
Brisa del Mar Torres-Martínez ${ }^{1}{ }^{(0)}$, Rey David Vargas-Sánchez ${ }^{1,2}{ }^{\circledR}$, Gastón Ramón Torrescano-Urrutia ${ }^{1}$, \\ Martin Esqueda ${ }^{1}$, Javier Germán Rodríguez-Carpena ${ }^{3}{ }^{\circledR}$, Juana Fernández-López ${ }^{4}{ }^{\oplus}$, Jose Angel Perez-Alvarez ${ }^{4}(\mathbb{D}$ \\ and Armida Sánchez-Escalante ${ }^{1, *(1)}$
}

1 Coordinación de Tecnología de Alimentos de Origen Animal (CTAOA), Centro de Investigación en Alimentación y Desarrollo, A.C. (CIAD), Carretera Gustavo Enrique Astiazarán Rosas 46, Hermosillo 83304, Mexico; brisa.torres@estudiantes.ciad.mx (B.d.M.T.-M.); rey.vargas@ciad.mx (R.D.V.-S.); gtorrescano@ciad.mx (G.R.T.-U.); esqueda@ciad.mx (M.E.)

2 Consejo Nacional de Ciencia y Tecnología, Av. Insurgentes Sur, 1582, México City 03940, Mexico

3 Unidad Académica de Medicina Veterinaria y Zootecnia, Universidad Autónoma de Nayarit, Compostela 67300, Mexico; german.rc@uan.edu.mx

4 IPOA Research Group, Centro de Investigación e Innovación Agroalimentaria y Agroambiental, Miguel Hernández University (CIAGRO-UMH), Orihuela, 03312 Alicante, Spain; j.fernandez@umh.es (J.F.-L.); ja.perez@umh.es (J.A.P.-A.)

* Correspondence: armida-sanchez@ciad.mx; Tel.: +52-662-289-2400

\section{check for} updates

Citation: Torres-Martínez, B.d.M. Vargas-Sánchez, R.D.;

Torrescano-Urrutia, G.R.; Esqueda, M.; Rodríguez-Carpena, J.G.; Fernández-López, J.; Perez-Alvarez, J.A.; Sánchez-Escalante, A. Pleurotus Genus as a Potential Ingredient for Meat Products. Foods 2022, 11, 779. https://doi.org/10.3390/ foods11060779

Academic Editor: Tomas Bolumar

Received: 10 February 2022

Accepted: 4 March 2022

Published: 8 March 2022

Publisher's Note: MDPI stays neutral with regard to jurisdictional claims in published maps and institutional affiliations.

Copyright: (C) 2022 by the authors. Licensee MDPI, Basel, Switzerland. This article is an open access article distributed under the terms and conditions of the Creative Commons Attribution (CC BY) license (https:// creativecommons.org/licenses/by/ $4.0 /)$.

\begin{abstract}
Edible mushrooms are considered an important source of nutritional and bioactive compounds. In this review, the findings of macronutrients, bioactive compounds, antioxidant activity, and antimicrobials against foodborne pathogens of some Pleurotus spp., as well as their potential use as an ingredient in the meat industry are discussed. The results show that Pleurotus spp. are an important source of proteins and amino acids, carbohydrates, minerals, and vitamins. Additionally, the presence of some bioactive components, such as polysaccharides ( $\alpha$-glucans, $\beta$-glucans, and so on), proteins /enzymes and peptides (eryngin, pleurostrin, and others) phenolic acids ( $p$-coumaric, chlorogenic, cinnamic, ferulic, gallic, protocatechuic, and others) and flavonoids (chrysin, naringenin, myricetin, quercetin, rutin, or the like) has been demonstrated. Several works evidenced the use of Pleurotus spp. in some meat and meat products (patties, sausages, paste, and suchlike) as a novel ingredient in order to improve their chemical composition and functional health promoting properties, as well as to increase their physicochemical and sensory attributes. In conclusion, the use of Pleurotus is a promissory strategy for the development of natural additives rich in nutritional and bioactive components for meat and meat product formulation.
\end{abstract}

Keywords: edible mushrooms; chemical composition; bioactive compounds; meat products

\section{Introduction}

One of the oldest food products with a record of their use are edible mushrooms, which are recognized for their nutritional and culinary value, thanks to their unique taste and texture. Furthermore, in recent decades, their potential biological activity has been proven; this is attributed to the presence of secondary metabolites. Consequently, in the presence of these, fungi show antioxidant, hypocholesterolemic, antimicrobial, immunomodulatory activity, among others. Thus, mushrooms can be considered functional foods since they can provide health benefits beyond the nutrients that they contain [1].

According to their usefulness, mushrooms can be divided into four categories: edible, medicinal, poisonous mushrooms, and finally, those whose properties remain less defined, including a significant number of these. Furthermore, they can be classified into various ecological groups, of which the most important are the saprophytes; Other classifications are based on growth with soil, mycorrhizal, lignicolous, hallucinogens, and coprophilous [2,3].

Edible mushrooms can be defined as "macro fungus with a distinctive fruiting body, which can be epigeal (above ground) or hypogeal (below ground) and large enough to 
be seen with the naked eye and picked by hand" [1]. The fruiting bodies are found mainly on the ground, varying in size, shape, and coloration for each species. These have filamentous bodies delimited by cell walls, are not mobile, and reproduce sexually and asexually by spores. They grow from spacious mycelia (hyphae), mainly underground, by the fruiting process. The mycelium is the vegetative part of a fungus. It consists of a system of branching hyphae through the soil, compost or substrate, the wood trunk, or other lignocellulosic material. After a period of growth and under favorable conditions, the established (matured) mycelium produces a fruitful structure called "fungus" [4,5].

Nowadays, mushrooms are used in medicine, pharmacy, food, and fermentation fields; they are considered a rich source of protein because they contain all essential amino acids, plus fiber and little fat. Likewise, they provide significant amounts of vitamins and bioactive compounds, such as unsaturated fatty acids, phenolic compounds, tocopherols, and carotenoids [6].

Many countries consume mushrooms as a delicacy, particularly for their aroma and texture, fiber content, in addition to their low energy intake. According to the rules of mycological nomenclature, there are around 120,000 species of fungi, which represent $3-8 \%$ of the estimated number of species existing on Earth. More than 2000 species are safe for consumption, and approximately 700 species are known to possess significant pharmacological properties [5,7]. Technological improvements have made its cultivation possible all over the world; the production of mushrooms on a global scale is represented by about $85 \%$ by five main species or genera: Agaricus bisporus (estimated at $30 \%$ of the world mushroom production), the genus Pleurotus (from five to six species cultivated in approximately $27 \%$ ), Lentinula edodes (17\%), Auricularia (6\%), and Flammulina (5\%) [8].

Pleurotus ostreatus is one of the most relevant edible fungi at the production level, a saprophytic fungus characterized by having bioactive compounds, mainly of phenolic origin. In the last decades, its utilization has grown due to the potential beneficial effects that its consumption can contribute to health. Even though the demand for mushrooms has been outstanding: growing to satisfy it, the yield is rarely doubled in today's agriculture [9].

Moreover, meat and meat products are essential for the human diet due to their nutritional components, including proteins, fats, minerals, vitamins, etc. However, some of these components are associated with human health risks, as well as related to loss of quality [10]. In this way, the meat industry modified meat products by incorporating natural additives (rosemary, grape, avocado, green tea, cocoa, broccoli, edible mushroom, among others) in order to replace nutritional components, increase functional-health promoting components, and enhance biological activity [10-12].

Therefore, the present review summarizes relevant studies about the composition, bioactive properties, and uses of Pleurotus spp. as a natural food additive for meat and meat products.

\section{Pleurotus spp.}

Pleurotus spp., are edible mushrooms from the Basidiomycetes that belong to the Pleurotaceae family (Agaricales, Agaricomycetes), commonly known as "oyster mushrooms" because of the form of their fruiting bodies. These species are the second most important in the commercial context. These mushrooms are popular due to their texture, aroma, and taste besides the possible effect on human health for the bioactive compounds (polysaccharides, $\beta$-glucans, considered as proven functional food $[13,14]$, proteins/enzymes, peptides, lectins, terpenoids, polyketides, and phenolic compounds) it has which could be applied as medicines or to the human diet. This genus comprises about 200 spices, which are distributed worldwide, and can be found in ecological niches, more preferably rotten tree trunks and branches but can be grown in a wide range of temperate and tropical climates; oyster mushroom preferentially decays lignin instead of polysaccharides. For this reason, they are known as white rot fungi [15-18]. The species have carpophores with eccentric pileus and decurrent blades that show a white or hyaline color enhanced by cylindrical or oval shapes like an oyster shell [19]. 
The Pleurotus genus is among the species with the highest production worldwide. The species of fungi of this genus exhibit multidirectional effects that promote health. Additionally, it is called the poor man's meat this is because a variety of substrates considered waste are used to grow mushrooms in rural conditions, which makes mushroom proteins more affordable and more available than proteins of animal origin. Some authors suggest that edible mushrooms can be classified as a functional food due to the possible positive effect that their consumption causes on the human body [20-23].

These mushrooms are capable of colonizing and degrading many lignocellulosic residues (cotton waste, walnut shell, straws of rice, wheat, sorghum, maize, wood), and they are a source of important nutrients and healing properties. Compared to other types of mushrooms, these require less growth time and are relatively rarely attacked by diseases and pests $[24,25]$.

Within the genus Pleurotus, the most common species are grey abalone oyster ( $P$. sajor$c a j u)$, recently classified on Lentinus genera, pink oyster mushroom (P. djamor), king oyster mushroom (P. eryngii), golden oyster (P. citrinopileatus), branched oyster mushroom (P. cornucopiae), king tuber oyster mushroom (P. tuber-regium), phoenix oyster (P. pulmonarius), abalone mushroom ( $P$. cystidiosus), white ferula mushroom (P. nebrodensis), and oyster mushroom (P. ostreatus; Figure 1) [15].

\section{Taxonomic Description}

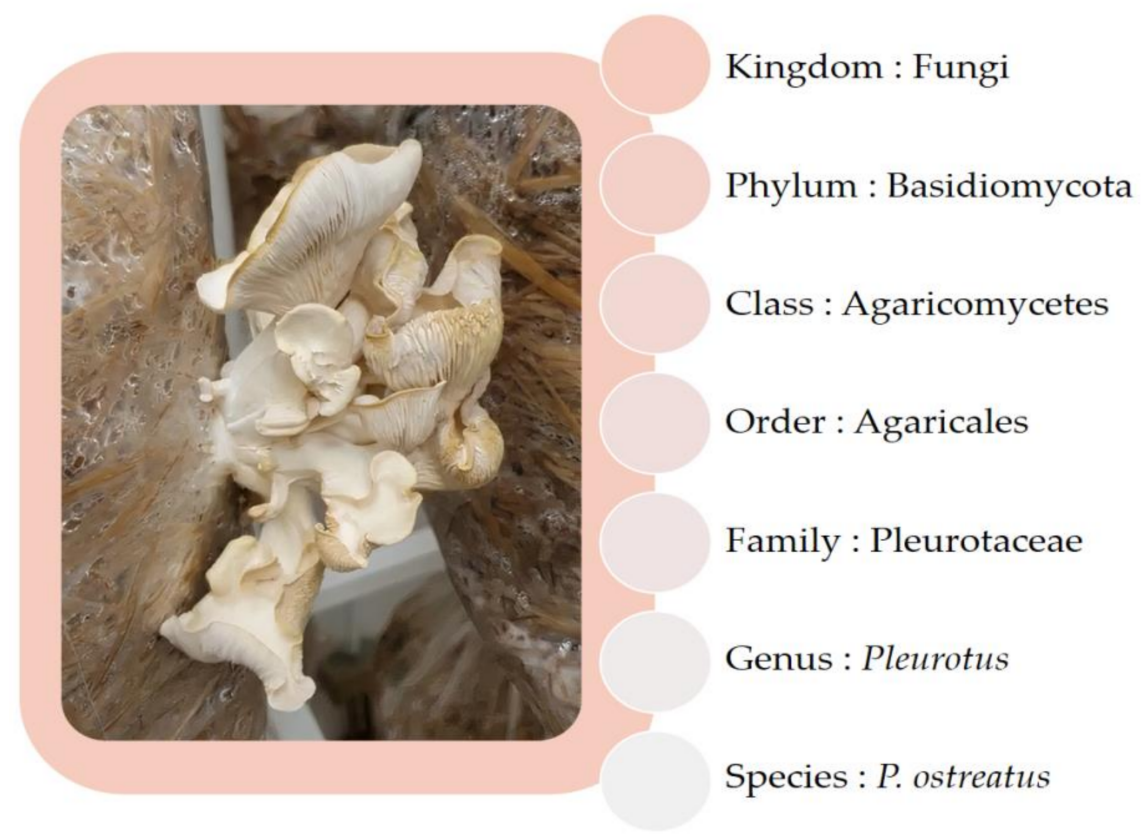

Figure 1. Taxonomic description and fruit bodies of Pleurotus ostreatus.

\section{Macro and Micronutrients}

The approximate chemical composition of Pleurotus spp. (Table 1) has been reported in previous works. Its fruiting body and mycelial biomass composition are determined by a range of characteristic aromas and flavors that are due to carbohydrates, lactones, amino acids, and terpenes [26]. These include high protein content, and essential amino acids enabling it to be as a substitute for meat diet; a chitin rich wall acts as a source of dietary fiber, vitamin content $\left(B_{1}, B_{2}, B_{12}, C, D\right.$, and $\left.E\right)$, micro and macro-elements, carbohydrates, low fat content, and almost zero cholesterol content. In relation to its composition of chemical structures, such as secondary metabolites, such as betalains and alkaloids, as well as glycoproteins and polysaccharides, Pleurotus genus is one of the most diverse edible and medicinal mushrooms [27]. 
Table 1. Proximate composition (\% dry matter) of some Pleurotus species.

\begin{tabular}{cccccc}
\hline Species & Protein & Fat & Ash & Carbohydrates & Reference \\
\hline P. ostreatus & 7 & 1.4 & 5.7 & 85.9 & {$[28]$} \\
P. eryngii & 11.0 & 1.5 & 6.2 & 81.4 & {$[29]$} \\
P. pulmonarius & 23.2 & 4.2 & 4.8 & 50.1 & {$[30]$} \\
P. sajor-caju & 26.34 & 3.67 & 10.37 & 38.17 & {$[31]$} \\
P. florida & 20.56 & 4.3 & 9.02 & 42.83 & {$[32]$} \\
\hline
\end{tabular}

Concerning their chemical composition, the mushrooms cultivated commercially are characterized by showing a similar profile of nutritional components compared to wild mushrooms. However, there may be certain differences related to their qualitative and quantitative composition, which will depend on factors, such as the strain of the fungus, the extraction process of the chemical compounds from the morphological parts of the fungus, and to a large extent on the conditions adopted during the cultivation process [33].

P. ostreatus can be considered an important source of proteins (7.3-53.3\%); compared with other foods, oyster mushrooms have all nine essential amino acids, for this reason, are ranked below animal meats and can be considered as a substitute for a meat diet. However, the amount of protein can be variable it has been reported that many factors affect it, such as the stage of maturation, the type of mushroom, the harvest location, and availability of nitrogen content in the medium; therefore, if a substrate rich in nitrogen or supplemented with nitrogen sources is used in the cultivation of it, the protein content could be higher [16,34-36].

Pleurotus spp. has an important amount of carbohydrates (50-60\% dry weight); these consist principally of sugars (oligosaccharides, monosaccharides, and disaccharides) which are correlated to the synthesis of polysaccharides. Generally, these are represented by fiber, such as glycoproteins that include chitin, $\alpha-\beta$, and glucans, cellulose, besides other hemicelluloses, such as mannans, galactans, and xylans [16,36,37].

About minerals, in general, Pleurotus species are an important source, contain a mix of nutritionally essential minerals, such as potassium (933-967 mg/100 g), notable levels of phosphorus (212-224 mg/100 g), calcium (221-238 mg/100 g), magnesium (366-407 mg/100 g), and in minor level sodium $(40-46 \mathrm{mg} / 100 \mathrm{~g})$, these represents the majority of fruit bodies, other minerals include copper (465-732 $\mu \mathrm{g} / \mathrm{g})$, zinc (113-131 mg/100 g), iron (105-112 $\mu \mathrm{g} / \mathrm{g})$, and cadmium $(5-35 \mu \mathrm{g} / \mathrm{g})$, which represents minor components [16,37-40].

Regarding micronutrients, Pleurotus could be an important source of vitamins, such as niacin, riboflavin, and folates, as good as vegetables, but the bioavailability of the latter is better for folic acid in contrast to peas or spinach. Furthermore, mushrooms contain a minor amount of vitamin $C(12-15 \mathrm{mg} / 100 \mathrm{~g})$ and thiamine $\left(B_{1}\right)(0.2-0.4 \mathrm{mg} / 100 \mathrm{~g})$, niacin (vitamin $\left.B_{5}\right)(6-9 \mathrm{mg} / 100 \mathrm{~g})$, pyridoxine (vitamin $\left.B_{6}\right)(0.1 \mathrm{mg} / 100 \mathrm{~g})$, retinol (vitamin $A$ ) $(25-26 \mu \mathrm{g} / 100 \mathrm{~g})$, riboflavin $\left(B_{2}\right)(0.5-0.7 \mathrm{mg} / 100 \mathrm{~g})$, and ergocalciferol $\left(D_{2}\right)(0.8-0.9 \mu \mathrm{g} / \mathrm{g})$ among others $[16,37,41-45]$.

This genus, characterized by their low-fat content, and therefore, are classified as low calorific food, with a small quantity of cholesterol and fat, lower than $4 \%$. However, as mentioned above, this amount depends on the substrate used in the cultivation. It has been reported that the most dominant unsaturated fatty acid in mushrooms is linolenic acid (C18:2), an essential fatty acid, which is essential for the production and conversion of flavor components in Pleurotus. Besides, other fatty acids reported are oleic (C18:1) and palmitic (C16:0) [16,35,42,46].

\section{Bioactive Compounds and Their Activity}

Plant material composition includes a wide content of physiologically active compounds, which exert beneficial effects on human health and can reduce the risk of some chronic diseases. In addition, the human health benefits and the functional potential of these active compounds in the food industry have been demonstrated. In this context, mushrooms are becoming increasingly popular as a source of nutritional, nutraceutical, 
and functional components [1,15]. Previously, the presence of some bioactive components of Pleurotus spp. has been evidenced. The Bioactive compounds in Pleurotus mushrooms include high and low molecular weight. Polysaccharides ( $\beta$-glucans), proteins/enzymes, and peptides are included in the high molecular compounds division, as for the low side, fatty acids, esters, terpenes, and polyphenols can be found [20]. For example, it has been reported that $P$. ostreatus extracts have antiviral, antiproliferative, anti-inflammatory activity, among others, which are associated with dietary fiber and other polysaccharides' biological activity [15,34,47]. Additionally, the anti-inflammatory effects of Pleurotus spp. have been demonstrated when using in vivo models against dermatitis and arthritis [47]. While in another study, it was observed that supplementation of $\beta$-glucans $(1 \mathrm{mg} / \mathrm{kg})$ isolated from P. ostreatus decreased swelling and arthritic scores in rats [48]. One of the primary antioxidants is the phenolic compounds; these are mainly free radical scavengers that prolong or delay the beginning of lipid oxidation, decreasing the formation of the volatile decomposition products, which could cause rancidity [49]. Regarding phenolic compounds, Pleurotus spp. contain several types (Table 2), including phenolic acid whose bioactivity and antioxidant properties are associated with the ring structures attached with the phenolic hydroxyl groups, and flavonoids, which are extensively associated with their human health benefits and with its functional potential in food matrices [15,50,51].

Table 2. Phenolic components identified in some Pleurotus spp.

\begin{tabular}{|c|c|c|}
\hline Specie & Compound & References \\
\hline \multirow{3}{*}{ P. ostreatus } & $\begin{array}{l}\text { Phenolic acids: gallic, protocatechuic, cinnamic, } p \text {-coumaric, } \\
\text { ferulic }\end{array}$ & {$[52]$} \\
\hline & Flavonoids: chrysin & \\
\hline & $\begin{array}{c}\text { Phenolic acids: chlorogenic, syringic, ferulic, cinnamic, } \\
\text { p-coumaric, caffeic, vanillic } \\
\text { Flavonoids: naringenin }\end{array}$ & {$[53]$} \\
\hline \multirow[t]{2}{*}{ P. pulmonarius } & $\begin{array}{l}\text { Phenolic acids: gallic, homonogentisic, protocatechuic, } \\
\text { chlorogenic, vanillic } \\
\text { Flavonoids: (+)-catechin, naringin, myricetin, resveratrol, } \\
\text { quercetin }\end{array}$ & {$[54]$} \\
\hline & Phenolic acids: gallic, caffeic, vanillic, $p$-coumaric, ferulic & {$[55]$} \\
\hline \multirow{3}{*}{ P. eryngii } & $\begin{array}{l}\text { Phenolic acids: 2,4-dihydroxybenzoic, chlorogenic, syringic, } \\
\text { ferulic, cinnamic, } p \text {-coumaric, caffeic, vanillic } \\
\text { Flavonoids: naringenin }\end{array}$ & {$[53]$} \\
\hline & $\begin{array}{l}\text { Phenolic acids: chlorogenic, } p \text {-hydroxybenzoic, } p \text {-anisic, ferulic, } \\
\text { sinapic, syringic, vanillic } \\
\text { Flavonoids: catechin, epicatechin, rutin, myricetin, hesperidin, } \\
\text { quercetin }\end{array}$ & {$[56]$} \\
\hline & Flavonoids: rutin & [57] \\
\hline P. sajor-caju & Phenolic acids: cinnamic & {$[51]$} \\
\hline
\end{tabular}

\subsection{Antioxidant Activity}

Diverse stress factors could disrupt normal cellular functions and initiate chain reactions that compromise the integrity of cells, consequently producing high amounts of reactive oxygen species. The generation of these metabolites can damage cellular structures (oxidation of lipids and proteins). One of the most controversial topics in chemistry is the oxidation of lipids and proteins in food [58,59]. Furthermore, deficiency in endogenous antioxidant defense can result in oxidative stress associated with various health problems, including coronary heart disease, among others [60]. Therefore, in various research works, the antioxidant effect of extracts obtained from P. ostreatus against the formation of radicals that affect human health has been evaluated [61]. Jayakumar et al. [41] assessed the potential of an ethanolic extract of $P$. ostreatus to inhibit the damage of deoxyribose mediated by hydroxyl radicals, finding that the eliminating effect of the hydroxyl radical of the fungus extract, at a concentration of $10 \mathrm{mg} / \mathrm{mL}$, was of $56 \%$. The antioxidant compounds 
found in the fruiting bodies, the mycelium, and the mushroom culture can be phenolic acids, polysaccharides, tocopherols, flavonoids, carotenoids, glycosides, ergothioneine, and ascorbic acid [8]. Although the antioxidant activity of Pleurotus spp., also has been associated with some proteins/enzymes and peptides [62].

Acosta-Urdapilleta et al. [44] reported the inhibition of $\mathrm{ABTS}^{\bullet+}$ and $\mathrm{DPPH}^{\bullet}$ radicals from $96 \%$ to $53 \%$ and $98 \%$ to $24 \%$, respectively, in the evaluation of antioxidant activity; P. citrinopileatus, showed the highest antioxidant activity. In another study, the assessment of antioxidant activities, and bioactive compounds of P. sajor-caju was evaluated. High inhibition $(>50 \%)$ of the $\mathrm{DPPH}^{\bullet}$ radical with methanolic extract of the P. sajor-caju was recorded $(67 \%)$, which could be associated with the presence of flavonoids, alkaloids, and phenolic bioactive metabolites [63]. The antioxidant activity of Pleurotus ostreatus has been reported; methanolic extracts showed inhibition of the $\mathrm{DPPH}^{\bullet}$ radical from 47 to up 50\% in a study by Stefan et al. [64]; also report activity of $20 \%$ of inhibition of ABTS ${ }^{\bullet+}$ radical and 74 to $79 \%$ of chelating activity. Ghosh et al. [65] compared the antioxidant properties and made a phytochemical screening of extracts from three cultivated Pleurotus species, P. eous, P. florida, and P. ostreatus. In their study results reported a high amount of phenols (13.03 $\mu \mathrm{g}$ gallic acid equivalent $/ \mathrm{mg}$ of extract), flavonoids ( $3.57 \mu \mathrm{g}$ quercetin equivalent $/ \mathrm{mg}$ of extract), and ascorbic acid ( $16.66 \mu \mathrm{g} / \mathrm{mg}$ of extract) for the P. eous extracts; furthermore, potential free radical scavenging, the extract showed inhibition $>50 \%$ of the $\mathrm{DPPH}^{\bullet}$ radical (P. florida $64 \%$, P. ostreatus $67 \%$ and P. eous $72 \%$ ); while the inhibition of the ABTS ${ }^{\bullet+}$ radical showed scavenging from $20 \%$ to $78 \%$. In another report, Fasoranti et al. [66], exhibit the antioxidant activity of P. pulmonarius and P. ostreatus, cultivated on substrate fortified with selenium, and the results showed a range of $27 \%$ to $97 \%$ of DPPH ${ }^{\bullet}$ scavenging effect at concentrations of 50 and $250 \mu \mathrm{g} / \mathrm{mL}$, respectively, whereas $69 \%$ to $91 \%$ of hydroxyl ion scavenging ability.

\subsection{Antimicrobial Activity}

Another property of great interest is its antimicrobial activity, which has been extensively evaluated in vitro. Shen et al. [67], reported inhibition of pathogenic bacteria, both Gram-positive (Bacillus, Clostridium perfringens, Staphylococcus spp.) and Gram-negative (Escherichia coli, Klebsiella pneumonia, Pseudomonas aeuroginosa, Salmonella spp., Shigella spp.), by extracts of $P$. ostreatus [67,68]. Akyuz and Kibag [69] evaluated the antimicrobial activity of P. eryngii cultivated on two different substrates, using the disk diffusion method. In the study, they reported that its extracts inhibited the growth of microorganisms $(7.7-10.3 \mathrm{~mm})$, E. coli, S. aureus, among others. The antimicrobial activity of P. plulmonarius was evaluated by Adebayo et al. [70] using the agar well diffusion technique. The results show the major inhibition zone was shown for S. aureus $(30 \mathrm{~mm})$, while the smallest zone size was obtained against $E$. coli $(7 \mathrm{~mm})$. Additionally, the antimicrobial potential of P. ostreatus fruiting body and mycelium extracts against Candida albicans, E. coli, and B. subtilis has been evidenced [71].

Extracts of fruiting body powder from P. ostreatus, showed antimicrobial activity against $C$. albicans; the result of the assay showed the formation of barriers on the extract concentration zone of $10.8 \mathrm{~mm}$ width [72]. A comparative study of Pleurotus spp. realized by Sathyan et al. [73], showed antimicrobial activity against E. coli, P. aeruginosa and K. pneumonia from P. ostreatus, P. djamor, and P. enryngii, respectively. Likewise, Adebayo et al. [74] evaluated antibacterial properties of hydroalcoholic extracts from four species of Pleurotus following the minimal inhibitory concentration and the minimal bactericidal concentration assays, finding that most bacteria were susceptible to a minimal inhibitory concentration in a range from 11 to $100 \mu \mathrm{g} / \mathrm{mL}$ of mushroom extracts, while only two of the Pleurotus spp. extracts showed bactericidal activity; they showed a bactericidal effect to Stenotrophomonas spp. from P. ostreatus; while P. tuber-regium showed a bactericidal effect for Streptococcus agalactiae, E. coli, B. subtilis, and P. aeruginosa. In another study, Pandey et al. [75] showed the antimicrobial activity of methanol extracts of $P$. flabellatus; the highest activity was reported against Proteus mirabilis, these results could be attributed to the presence of secondary 
metabolites, such as amino acids, alkaloids, flavonoids, etc. Although the antibacterial activity of proteins/enzymes has also been demonstrated, as well as peptides from Pleurotus spp. For example, the antibacterial properties of $P$. eryngii and $P$. ostreatus have been investigated against Bacillus sp. and associated with the presence of eryngeolysin and ostreolysin proteins, respectively [76].

\subsection{Biological Activity}

P. ostreatus also has shown other interesting healthy properties. As mentioned above, fungi have an important source of carbohydrates (polysaccharides) in their cell walls; a beneficial effect on health has been reported, and this activity is mainly related to its immunomodulatory and anticancer properties. These polysaccharides induce the immune system through dectin-1, CR3, and lactosylceramide sequestering receptors, which are involved in macrophage activation, phagocytosis, and cytokine production. Likewise, they can activate neutrophil complement receptors [15]. Studies conducted by Radzki et al. [47] isolated water-soluble polysaccharides (WSP) from P. ostreatus fruiting body and tested their antiproliferative activity against MCF-7 and T-47D breast cancer cell lines; the results showed that the most evident effect was obtained when using a concentration of $250 \mathrm{mg} / \mathrm{mL}$, obtaining cell viability of 65 and 72\%, respectively.

Another important biological property of this fungus is its antihypercholesterolemic activity. Research by Alam et al. [77], evaluated the effect of the inclusion of $5 \%$ of $P$. ostreatus flour in the diet of hypercholesterolemic rats on liver and kidney functions. The results obtained in this study showed a decrease of $21 \%$ and $45 \%$ in the level of total cholesterol in plasma and triglycerides due to the diet added with P. ostreatus, respectively.

Thus, Corrêa et al. [34] mentioned that this mushroom has antinociceptives, hypoglycemic and hypolipidemic effects, in addition to other interesting effects, such as cytoprotectors, prevention of skin aging, neurogenic and anticataratogenic.

\section{Pleurotus spp. as an Ingredient in Meat Products}

Food additives are substances deliberately added to food in small amounts along production or processing to enhance its organoleptic characteristics, besides, to delay deterioration during storage and protect the consumer against food poisoning [78]. According to the Food Protection Committee of the Food and Nutrition Board, food additives are defined as ingredients or mixtures of different ingredients, other than a basic food product, which are present in food because of any aspect of storage, processing, production, or packaging. Additives can be classified into six main categories: nutritional additives, texturizers, preservatives, miscellaneous additives, flavorings, and colorants [79].

In this context, during meat product processing, synthetic and natural chemical compounds (GRAS, generally recognized as safe) are used to ensure the safety and quality of the final product. It is well known that raw muscle and fat are the principal ingredients in a meat product. While, food additives, including non-meat ingredients, such as small molecules (phosphate, salt, antimicrobial, and antioxidant compounds that can be found in plants, spices, among others) or bigger molecules (proteins, gums, starch, non-muscle, among others), are also used to enhance meat and meat product quality [80].

Lipid and protein oxidation, along with microbial contamination, are the main cause of spoilage in meat and meat products and are closely associated with the appearance of undesirable changes in color, taste, texture, and nutritional value. To maintain quality standards, the meat industry has used natural antioxidants to reduce these problems. Previous studies have shown that plant materials, such as edible mushrooms are extensively investigated due to the potential they may have as a food ingredient $[10,81]$.

Moreover, to ensure the safety of an edible mushroom when used as a food ingredient, it is important to know its microbial load and identify its allergenic components. In previous work, the microbial load and the occurrence of foodborne pathogens of fresh and stored edible mushroom ( $P$. ostreatus and P. eryngii) was investigated. The results revealed that samples showed low contamination (aerobic mesophilic bacteria $<5.0 \mathrm{log} \mathrm{cfu} / \mathrm{g}$ ), however, 
the microbiological quality was reduced during mushroom storage $\left(4^{\circ} \mathrm{C}\right.$ for 12 days). Regarding identified foodborne pathogens, Pseudomonas fluorescens and Ewingella americana were the most abundant bacteria. In addition, Salmonella spp., L. monocytogenes and Bacillus cereus were absent in the tested samples [82]. In addition, it has been reported that Pleurotus spp. spores are associated with some allergy risks, such as asthma and acute IgE-mediate rhinoconjunctivitis in sensitized individuals, therefore, research has been carried out to reduce the content of spores through mutation processes [83].

The technological properties that Pleurotus spp. could provide to meat products have been reported; for example, Stephan et al. [84] evaluated the mycelia of $P$. sapidus as a protein source in a vegan boiled sausage and compared it to commercial proteins and meat sausages. The results showed enhancement in the texture profile of the vegan sausage and similar flavor after production.

Considering the health benefits and functional properties of edible mushrooms, Pleurotus can be proposed as a potential source of natural additives to improve meat and meat products' quality (Table 3).

Table 3. Pleurotus spp. enhanced meat products quality.

\begin{tabular}{|c|c|c|c|}
\hline Meat Product & Mushroom & Relevant Results & Reference \\
\hline \multirow{5}{*}{ Chicken patties } & P. sajor-caju/fresh ground & $\begin{array}{c}\text { Decreased lightness, yellowness, hardness, and chewiness } \\
\text { while increase springiness }\end{array}$ & [85] \\
\hline & P. sajor-caju/fresh ground & Low fat content without threatening sensorial properties & [86] \\
\hline & P. sapidus/flour & Highest antioxidant activity & [87] \\
\hline & P. sajor-caju/fresh ground & $\begin{array}{l}\text { Reduction of fat, increased the ash content, no difference } \\
\text { recorded in sensory attributes }\end{array}$ & [88] \\
\hline & P. sajor-caju/fresh ground & $\begin{array}{l}\text { Lower costs of production, enhancement of nutritional } \\
\text { composition }\end{array}$ & [89] \\
\hline \multirow[t]{2}{*}{ Chicken nugget } & Pleurotus sajor-caju/flour & $\begin{array}{c}\text { Higher lightness, chewiness, springiness, water activity, and } \\
\text { moisture }\end{array}$ & [90] \\
\hline & Pleurotus sajor-caju/fresh ground & $\begin{array}{l}\text { Increased moisture and fiber but reduced the ash content, } \\
\text { crude fat, and crude protein }\end{array}$ & [91] \\
\hline \multirow[t]{2}{*}{ Chicken sausage } & $\begin{array}{l}\text { Pleurotus ostreatus and } P \text {. } \\
\text { nebrodensis/Blanched }\end{array}$ & The addition improves the taste and texture & [92] \\
\hline & P. sajor-caju/flour & $\begin{array}{l}\text { Higher nutritional composition: increment total dietary } \\
\text { fiber, low fat content, and } \beta \text {-glucan except for protein }\end{array}$ & [93] \\
\hline $\begin{array}{l}\text { Beef brain } \\
\text { sausage }\end{array}$ & P. ostreatus/blanched paste & $\begin{array}{c}\text { 50:50 treatment presents the best characteristics and } \\
\text { preference in organoleptic test }\end{array}$ & [94] \\
\hline \multirow{4}{*}{ Beef patties } & P. eryngii/flour & $\begin{array}{l}\text { Lowest reduction in diameter, thickness, and weight loss } \\
\text { duringcooking, besides improved flavor, juiciness, } \\
\text { tenderness, and acceptance. }\end{array}$ & [95] \\
\hline & P. ostreatus / flour & $\begin{array}{c}\text { Reduce fat and sodium content besides cooking loss, } \\
\text { hardness, and gumminess }\end{array}$ & [96] \\
\hline & P. sajor-caju/fresh ground & Decreased fat content & [97] \\
\hline & P. ostreatus/blanched & $\begin{array}{l}\text { No significant differences in terms of appearance, aroma, } \\
\text { taste, and texture in comparison with control }\end{array}$ & [98] \\
\hline $\begin{array}{l}\text { Beef and chicken } \\
\text { patties }\end{array}$ & P. sajor-caju/fresh ground & Improved protein efficiency ratio & [99] \\
\hline Pork sausages & P. eryngii/deep fried & $\begin{array}{l}\text { Reduced fat and energy contents, while protein, moisture, } \\
\text { total dietary fiber, cooking loss, and water holding capacity } \\
\text { increased }\end{array}$ & [100] \\
\hline $\begin{array}{l}\text { Frankfurter } \\
\text { sausages }\end{array}$ & P. ostreatus/flour & Fiber contents were improved as well as texture & [96] \\
\hline
\end{tabular}


Table 3. Cont.

\begin{tabular}{|c|c|c|c|}
\hline Meat Product & Mushroom & Relevant Results & Reference \\
\hline \multirow{4}{*}{ Beef Meatballs } & P. ostreatus/ deep fried & $\begin{array}{l}\text { Higher protein, fat, better protein while lower cooking } \\
\text { losses }\end{array}$ & [101] \\
\hline & P. ostreatus/fresh ground & $\begin{array}{l}\text { It matched the physical properties to control treatment } \\
\text { (100\% meat) }\end{array}$ & [102] \\
\hline & P. ostreatus/fresh ground & $\begin{array}{l}\text { Enhanced the organoleptic characteristics and reduced the } \\
\text { fat content }\end{array}$ & {$[103]$} \\
\hline & P. ostreatus/fresh ground & Improved the chewiness & [104] \\
\hline Salami & P. ostreatus / flour & Prevent lipid and protein oxidation & [105] \\
\hline Beef paste & P. ostreatus/flour & $\begin{array}{l}\text { Reduce the hardness, chewiness, and gumminess. The } \\
\text { amino acids content and flavor component were enhanced }\end{array}$ & [106] \\
\hline $\begin{array}{c}\text { Abon Quail } \\
\text { shredded meat }\end{array}$ & P. ostreatus/fresh ground & $\begin{array}{l}\text { Reduce price and texture of quail, also increased moisture, } \\
\text { and decreased }\end{array}$ & [107] \\
\hline
\end{tabular}

Pleurotus spp. has been used in meat products to improve meat products. Table 3 shows the effects of the addition of Pleurotus spp. in different meat products. In this table, it can be observed that the most addressed aspects evaluated in these works are the effects of Pleurotus over the technological properties of these meat products, not only on fresh products also on cooked ones. Furthermore, another aspect that has been reported is the antioxidant effect that the addition of Pleurotus could have over the meat products; these can be associated with the bioactive compounds found in the edible mushroom. Besides the antioxidant effects, the flavor enhancement in the formulations and the sensory attributes have been reported too.

Despite the great benefits that the consumption of this mushroom brings, both to health and the potential use as a meat product ingredient, there is not much evidence about its use. Which opens an area of opportunity for the elaboration of products added with these mushrooms, as well as the study of the benefits that their consumption can provide to health.

\section{Conclusions}

Edible mushrooms, including some Pleurotus spp., have long been considered one of the most delicious and succulent foods worldwide. Furthermore, several studies demonstrated the presence of nutritional (proteins and amino acids, fat and fatty acids, vitamins, etc.) and biologically active components (i.e., polysaccharides, proteins/enzymes, peptides, phenolic compounds, among others), which are associated with their antioxidant and antimicrobial potential. On the other hand, it has been demonstrated the use of these mushroom species is an opportunity to improve, the nutritional and functional-health properties of meat (beef, chicken, and pork) and meat products (patties, nuggets, sausages, meatballs, Salami, paste, and others) as well as to enhance their quality.

Author Contributions: Writing—original draft preparation, B.d.M.T.-M., R.D.V.-S., G.R.T.-U., M.E., J.G.R.-C., J.F.-L., J.A.P.-A. and A.S.-E.; writing-review and editing, B.d.M.T.-M., R.D.V.-S., G.R.T.-U., M.E., J.G.R.-C., J.F.-L., J.A.P.-A. and A.S.-E. All authors have read and agreed to the published version of the manuscript.

Funding: This research received no external funding.

Acknowledgments: Brisa del Mar Torres-Martínez gratefully acknowledges a fellowship from CONACYT for PhD studies.

Conflicts of Interest: The authors declare no conflict of interest. 


\section{References}

1. Chang, S.T. Overview of Mushroom Cultivation and utilization as functional foods. In Mushrooms as Functional Foods; Cheung, P.C.K., Ed.; John Wiley \& Sons: Hoboken, NJ, USA, 2008; pp. 1-33. [CrossRef]

2. Baker, T. Origins of the word 'Mushroom'. Mycologist 1989, 3, 88-90. [CrossRef]

3. Chang, S.T.; Wasser, S.P. The Cultivation and environmental impact of mushrooms. Oxf. Res. Encycl. Environ. Sci. 2017. [CrossRef]

4. Blackwell, M.; Spatafora, J.W. Fungi and their allies. In Biodiversity of Fungi: Inventory and Monitoring Methods; Mueller, G.M., Bills, G.F., Foster, M.S., Eds.; Academic Press: Burlington, VT, USA, 2004; pp. 7-21. [CrossRef]

5. Kalač, P. Chemical composition and nutritional value of European species of wild growing mushrooms: A review. Food Chem. 2009, 113, 9-16. [CrossRef]

6. $\quad$ Saritha, K.V.; Prakash, B.; Khilare, V.C.; Khedkar, G.D.; Reddy, Y.M.; Khedkar, C.D. Mushrooms and truffles: Role in the diet. In Encyclopedia of Food and Health; Caballero, B., Finglas, P.M., Toldrá, F., Eds.; Academic Press: Cambridge, MA, USA, 2016; pp. 1-8. [CrossRef]

7. Hawksworth, D.L.; Lücking, R. Fungal Diversity Revisited: 2.2 to 3.8 Million Species. Microbiol. Spectr. 2017, 5, 1-17. [CrossRef] [PubMed]

8. Sánchez, C. Reactive oxygen species and antioxidant properties from mushrooms. Synth. Syst. Biotechnol. 2017, 2, 13-22. [CrossRef]

9. Royse, D.J. A Global Perspective On the High Five: Agaricus, Pleurotus, Lentinula, Auricularia \& Flammulina. In Proceedings of the 8th International Conference on Mushroom Biology and Mushroom Products, New Delhi, India, 19-22 November 2014.

10. Fernández-Ginés, J.M.; Fernández-López, J.; Sayas-Barberá, E.; Pérez-Alvarez, J.A. Meat Products as functional foods: A review. J. Food Sci. 2005, 70, R37-R43. [CrossRef]

11. Pérez Montes, A.; Rangel-Vargas, E.; Lorenzo, J.M.; Romero, L.; Santos, E.M. Edible mushrooms as a novel trend in the development of healthier meat products. Curr. Opin. Food Sci. 2021, 37, 118-124. [CrossRef]

12. Falowo, A.B.; Fayemi, P.O.; Muchenje, V. Natural antioxidants against lipid-protein oxidative deterioration in meat and meat products: A review. Food Res. Int. 2014, 64, 171-181. [CrossRef]

13. Food and Drug Administration. Food labeling: Health claims; soluble dietary fiber from certain foods and coronary heart disease Final rule. Fed. Regist. 2005, 70, 76150-76162.

14. EFSA. Scientific Opinion on the substantiation of health claims related to beta glucans and maintenance of normal blood cholesterol concentrations (ID 754, 755, 757, 801, 1465, 2934) and maintenance or achievement of a normal body weight (ID 820 , 823) pursuant. EFSA J. 2009, 7, 1254. [CrossRef]

15. Carrasco-González, J.A.; Serna-Saldívar, S.O.; Gutiérrez-Uribe, J.A. Nutritional composition and nutraceutical properties of the Pleurotus fruiting bodies: Potential use as food ingredient. J. Food Compos. Anal. 2017, 58, 69-81. [CrossRef]

16. El Enshasy, H.; Maftoun, P.; Johari, H.; Soltani, M.; Malek, R.A.; Othman, N. The Edible mushroom Pleurotus spp.: I. Biodiversity and nutritional values. Int. J. Biotechnol. Wellness Ind. 2015, 4, 67-83. [CrossRef]

17. Julian, A.V.; Reyes, R.G.; Eguchi, F. Agro-industrial waste conversion into medicinal mushroom cultivation. In Encyclopedia of Environmental Health, 2nd ed.; Nriagu, J.O., Ed.; Elsevier: Amsterdam, The Netherlands, 2019; pp. 13-20. [CrossRef]

18. Rodrigues Barbosa, J.; dos Santos Freitas, M.M.; da Silva Martins, L.H.; de Carvalho, R.N. Polysaccharides of mushroom Pleurotus spp.: New extraction techniques, biological activities and development of new technologies. Carbohydr. Polym. 2020, 229, 115550. [CrossRef]

19. Petre, M.; Petre, V. Biotechnology of mushroom growth through submerged cultivation. In Mushroom Biotechnology Developments and Applications; Petre, M., Ed.; Academic Press: San Diego, CA, USA, 2016; pp. 1-18. [CrossRef]

20. Golak-Siwulska, I.; Kałużewicz, A.; Spiżewski, T.; Siwulski, M.; Sobieralski, K. Bioactive compounds and medicinal properties of Oyster mushrooms (Pleurotus spp.). Folia Hortic. 2018, 30, 191-201. [CrossRef]

21. Öztürk, M.; Tel-Çayan, G.; Muhammad, A.; Terzioğlu, P.; Duru, M.E. Chapter 10-Mushrooms: A source of exciting bioactive compounds. Stud. Nat. Prod. Chem. 2015, 45, 363-456. [CrossRef]

22. Rodriguez Estrada, A.E.; Pecchia, J. Cultivation of Pleurotus ostreatus. In Edible and Medicinal Mushrooms: Technology and Applications; Cunha Zied, D., Pardo-Gimenez, A., Eds.; John Wiley \& Sons: Hoboken, NJ, USA, 2017; pp. 339-360.

23. Singdevsachan, S.K.; Auroshree, P.; Mishra, J.; Baliyarsingh, B.; Tayung, K.; Thatoi, H. Mushroom polysaccharides as potential prebiotics with their antitumor and immunomodulating properties: A review. Bioact. Carbohydrates Diet. Fibre 2016, 7, 1-14. [CrossRef]

24. Grabarczyk, M.; Mączka, W.; Wińska, K.; Uklańska-Pusz, C. Mushrooms of the Pleurotus genus-properties and application. Biotechnol. Food Sci. 2019, 83, 13-30. [CrossRef]

25. Sözbir, G.; Bektas, I.; Zulkadir, A. Lignocellulosic wastes used for the cultivation of Pleurotus ostreatus mushrooms: Effects on productivity. BioResources 2015, 10, 4686-4693. [CrossRef]

26. Smiderle, F.R.; Olsen, L.M.; Ruthes, A.C.; Czelusniak, P.A.; Santana-Filho, A.P.; Sassaki, G.L.; Gorin, P.A.J.; Iacomini, M. Exopolysaccharides, proteins and lipids in Pleurotus pulmonarius submerged culture using different carbon sources. Carbohydr. Polym. 2012, 87, 368-376. [CrossRef]

27. Sharma, A.; Sharma, A.; Tripathi, A. Biological activities of Pleurotus spp. polysaccharides: A review. J. Food Biochem. 2021, 45, e13748. [CrossRef] 
28. Agarwal, S.; Kushwaha, A.; Verma, V.; Singh, M.P. Nutritional attributes of pleurotus mushroom. In Incredible World of Biotechnology; Nova Science Publishers, Inc.: New York, NY, USA, 2017; pp. 13-24.

29. Patil, S.S.; Ahmed, S.A.; Telang, S.M.; Bailg, M.M.V. The nutritional value of Pleurotus ostreatus (jacq.:fr.) Kumm cultivated on different ligno-cellulosic agro-wastes. Innov. Rom. Food Biotechnol. 2010, 7, 66-76.

30. Cağlarirmak, N. Chemical composition and nutrition value of dried cultivated culinary-medicinal mushrooms from Turkey. Int. J. Med. Mushrooms 2011, 13, 351-356. [CrossRef] [PubMed]

31. Huang, S.J.; Lin, C.P.; Tsai, S.Y. Vitamin D2 content and antioxidant properties of fruit body and mycelia of edible mushrooms by UV-B irradiation. J. Food Compos. Anal. 2015, 42, 38-45. [CrossRef]

32. Valverde, M.E.; Hernández-Pérez, T.; Paredes-López, O. Edible Mushrooms: Improving Human Health and Promoting Quality Life. Int. J. Microbiol. 2015, 2015, 376387. [CrossRef] [PubMed]

33. Bellettini, M.B.; Fiorda, F.A.; Maieves, H.A.; Teixeira, G.L.; Ávila, S.; Hornung, P.S.; Júnior, A.M.; Ribani, R.H. Factors affecting mushroom Pleurotus spp. Saudi J. Biol. Sci. 2019, 26, 633-646. [CrossRef]

34. Corrêa, R.C.G.; Brugnari, T.; Bracht, A.; Peralta, R.M.; Ferreira, I.C.F.R. Biotechnological, nutritional and therapeutic uses of Pleurotus spp. (Oyster mushroom) related with its chemical composition: A review on the past decade findings. Trends Food Sci. Technol. 2016, 50, 103-117. [CrossRef]

35. Ritota, M.; Manzi, P. Pleurotus spp. Cultivation on different agri-food by-products: Example of biotechnological application Sustainability 2019, 11, 5049. [CrossRef]

36. Kumar, K. Nutraceutical potential and processing aspects of oyster mushrooms (Pleurotus species). Curr. Nutr. Food Sci. 2018, 16, 3-14. [CrossRef]

37. Raman, J.; Jang, K.-Y.; Oh, Y.-L.; Oh, M.; Im, J.-H.; Lakshmanan, H.; Sabaratnam, V. Cultivation and nutritional value of prominent Pleurotus spp.: An Overview. Mycobiology 2020, 49, 1-14. [CrossRef]

38. Bano, Z.; Rajarathnam, S.; Steinkraus, K.H. Pleurotus mushrooms. Part II. Chemical composition, nutritional value, post-harvest physiology, preservation, and role as human food. Crit. Rev. Food Sci. Nutr. 1988, 27, 87-158. [CrossRef]

39. Oyetayo, V.O.; Ogidi, C.O.; Bayode, S.O.; Enikanselu, F.F. Evaluation of biological efficiency, nutrient contents and antioxidant activity of Pleurotus pulmonarius enriched with Zinc and Iron. Indian Phytopathol. 2021, 74, 901-910. [CrossRef]

40. Muñoz, A.H.S.; Corona, F.G.; Wrobel, K.; Soto, G.M.; Wrobel, K. Subcellular distribution of aluminum, bismuth, cadmium, chromium, copper, iron, manganese, nickel, and lead in cultivated mushrooms (Agaricus bisporus and Pleurotus ostreatus). Biol. Trace Element Res. 2005, 106, 265-277. [CrossRef]

41. Jayakumar, T.; Thomas, P.A.; Geraldine, P. In-vitro antioxidant activities of an ethanolic extract of the oyster mushroom, Pleurotus ostreatus. Innov. Food Sci. Emerg. Technol. 2009, 10, 228-234. [CrossRef]

42. Sajon, S.R.; Sana, S.; Rana, S.; Rahman, S.M.; Nishi, Z.M. Mushrooms: Natural factory of anti-oxidant, anti-inflammatory, analgesic and nutrition. J. Pharmacogn. Phytochem. 2018, 7, 464-475.

43. Reis, F.S.; Barros, L.; Martins, A.; Ferreira, I.C.F.R. Chemical composition and nutritional value of the most widely appreciated cultivated mushrooms: An inter-species comparative study. Food Chem. Toxicol. 2012, 50, 191-197. [CrossRef]

44. Acosta-Urdapilleta, M.L.; Villegas, E.; Estrada-Torres, A.; Téllez-Téllez, M.; Díaz-Godínez, G. Antioxidant activity and proximal chemical composition of fruiting bodies of mushroom, Pleurotus spp. produced on wheat straw. J. Environ. Biol. 2020, 41, 1075-1081. [CrossRef]

45. Oyetayo, F.L.; Akindahunsi, A.A.; Oyetayo, V.O. Chemical profile and amino acids composition of edible mushrooms Pleurotus sajor-caju. Nutr. Health 2007, 18, 383-389. [CrossRef] [PubMed]

46. Alam, N.; Amin, R.; Khan, A.; Ara, I.; Shim, M.J.; Lee, M.W.; Lee, T.S. Nutritional Analysis of cultivated mushrooms in Bangladesh-Pleurotus ostreatus, Pleurotus sajor-caju, Pleurotus florida and Calocybe indica. Mycobiology 2008, 36, 228-232. [CrossRef]

47. Radzki, W.; Ziaja-Sołtys, M.; Nowak, J.; Rzymowska, J.; Topolska, J.; Sławińska, A.; Michalak-Majewska, M.; Zalewska-Korona, M.; Kuczumow, A. Effect of processing on the content and biological activity of polysaccharides from Pleurotus ostreatus mushroom. LWT 2016, 66, 27-33. [CrossRef]

48. Rovensky, J.; Stancikova, M.; Svík, K.; Bauerova, K.; Jurcovicová, J. The effects of b -glucan isolated from Pleurotus ostreatus on methotrexate treatment in rats with adjuvant arthritis. Rheumatol. Int. 2011, 31, 507-511. [CrossRef]

49. Shahidi, F.; Ambigaipalan, P. Phenolics and polyphenolics in foods, beverages and spices: Antioxidant activity and health effects-A review. J. Funct. Foods 2015, 18, 820-897. [CrossRef]

50. Heleno, S.A.; Martins, A.; Queiroz, M.J.R.P.; Ferreira, I.C.F.R. Bioactivity of phenolic acids: Metabolites versus parent compounds: A review. Food Chem. 2015, 173, 501-513. [CrossRef] [PubMed]

51. Kanagasabapathy, G.; Malek, S.N.A.; Kuppusamy, U.R.; Vikineswary, S. Chemical composition and antioxidant properties of extracts of fresh fruiting bodies of Pleurotus sajor-caju (Fr.) Singer. J. Agric. Food Chem. 2011, 59, 2618-2626. [CrossRef] [PubMed]

52. Vargas-Sánchez, R.D.; Torrescano-Urrutia, G.R.; Ibarra-Arias, F.J.; Portillo-Loera, J.J.; Ríos-Rincón, F.G.; Sánchez-Escalante, A. Effect of dietary supplementation with Pleurotus ostreatus on growth performance and meat quality of Japanese quail. Livest. Sci. 2018, 207, 117-125. [CrossRef]

53. Gąsecka, M.; Mleczek, M.; Siwulski, M.; Niedzielski, P. Phenolic composition and antioxidant properties of Pleurotus ostreatus and Pleurotus eryngii enriched with selenium and zinc. Eur. Food Res. Technol. 2016, 242, 723-732. [CrossRef]

54. Nguyen, T.K.; Im, K.H.; Choi, J.; Shin, P.G.; Lee, T.S. Evaluation of antioxidant, anti-cholinesterase, and anti-inflammatory effects of culinary mushroom Pleurotus pulmonarius. Mycobiology 2016, 44, 291-301. [CrossRef] 
55. Contato, A.G.; Inácio, F.D.; de Araújo, C.A.V.; Brugnari, T.; Maciel, G.M.; Haminiuk, C.W.I.; Bracht, A.; Peralta, R.M.; de Souza, C.G.M. Comparison between the aqueous extracts of mycelium and basidioma of the edible mushroom Pleurotus pulmonarius: Chemical composition and antioxidant analysis. J. Food Meas. Charact. 2020, 14, 830-837. [CrossRef]

56. Lin, J.-T.; Liu, C.-W.; Chen, Y.-C.; Hu, C.-C.; Juang, L.-D.; Shiesh, C.-C.; Yang, D.-J. Chemical composition, antioxidant and anti-inflammatory properties for ethanolic extracts from Pleurotus eryngii fruiting bodies harvested at different time. LWT 2014, 55, 374-382. [CrossRef]

57. Cikcikoglu Yildirim, N.; Türkoğlu, S.; Yildirim, N.; Kaplan Ince, O. Antioxidant properties of wild edible mushroom Pleurotus eryngii collected from Tunceli province of Turkey. Dig. J. Nanomater. Biostructures 2012, 7, 1647-1654.

58. Lund, M.N.; Heinonen, M.; Baron, C.P.; Estévez, M. Protein oxidation in muscle foods: A review. Mol. Nutr. Food Res. 2011, 55, 83-95. [CrossRef]

59. Jh, C. Lipid Oxidation in Meat. J. Nutr. Food Sci. 2016, 6, 1-3. [CrossRef]

60. Smolskaitè, L.; Venskutonis, P.R.; Talou, T. Comprehensive evaluation of antioxidant and antimicrobial properties of different mushroom species. LWT 2015, 60, 462-471. [CrossRef]

61. Piskov, S.; Timchenko, L.; Grimm, W.-D.; Rzhepakovsky, I.; Avanesyan, S.; Sizonenko, M.; Kurchenko, V. Effects of various drying methods on some physico-chemical properties and the antioxidant profile and ACE inhibition activity of oyster mushrooms (Pleurotus ostreatus). Foods 2020, 9, 160. [CrossRef] [PubMed]

62. Landi, N.; Clemente, A.; Pedone, P.V.; Ragucci, S.; Di Maro, A. An updated review of bioactive peptides from mushrooms in a well-defined molecular weight range. Toxins 2022, 14, 84. [CrossRef]

63. Kandasamy, S.; Chinnappan, S.; Thangaswamy, S.; Balakrishnan, S.; Khalifa, A.Y.Z. Assessment of antioxidant, antibacterial activities and bioactive compounds of the wild edible mushroom Pleurotus sajor-caju. Int. J. Pept. Res. Ther. 2020, 26, 1575-1581. [CrossRef]

64. Stefan, R.I.; Vamanu, E.; Angelescu, G.C. Antioxidant activity of crude methanolic extracts from Pleurotus ostreatus. Res. J. Phytochem. 2015, 9, 25-32. [CrossRef]

65. Ghosh, S.; Chatterjee, T.; Sardar, A.; Chatterjee, I.; Bose, A.; Dasgupta, A.; Malitha, A.; Acharya, K. Antioxidant properties and phytochemical screening of infusion and decoction obtained from three cultivated Pleurotus species: A comparative study. Jordan J. Pharm. Sci. 2020, 13, 121-129.

66. Fasoranti, O.F.; Ogidi, C.O.; Oyetayo, V.O. Nutrient contents and antioxidant properties of Pleurotus spp. cultivated on substrate fortified with Selenium. Curr. Res. Environ. Appl. Mycol. 2019, 9, 66-76. [CrossRef]

67. Shen, H.S.; Shao, S.; Chen, J.C.; Zhou, T. Antimicrobials from mushrooms for assuring food safety. Compr. Rev. Food Sci. Food Saf. 2017, 16, 316-329. [CrossRef]

68. Román, M.P.G.; Mantilla, N.B.; Flórez, S.A.C.; De Mandal, S.; Passari, A.K.; Ruiz-Villáfan, B.; Rodríguez-Sanoja, R.; Sánchez, S Antimicrobial and Antioxidant Potential of Wild Edible Mushrooms. In An Introduction to Mushroom; Passari, A.K., Sánchez, S., Eds.; IntechOpen: London, UK, 2020. [CrossRef]

69. Akyüz, M.; Kirbag, S. Antimicrobial activity of Pleurotus eryngii var. ferulae grown on various agro-wastes. EurAsian J. Biosci. 2009, 3, 58-63. [CrossRef]

70. Adebayo, E.A.; Oloke, J.K.; Ayandele, A.A.; Adegunlola, C.O. Phytochemical, antioxidant and antimicrobial assay of mushroom metabolite from Pleurotus pulmonarius-LAU 09 (JF736658). J. Microbiol. Biotechnol. Res. 2012, 2, 366-374.

71. Wolff, E.R.S.; Wisbeck, E.; Silveira, M.; Gern, R.M.M.; Pinho, M.S.L.; Furlan, S.A. Antimicrobial and antineoplasic activity of Pleurotus ostreatus. Appl. Biochem. Biotechnol. 2008, 151, 402-412. [CrossRef] [PubMed]

72. Gra, S.; Kusuma, I.W.; Arung, E.T.; Kuspradini, H. The potential of white-oyster mushroom (Pleurotus ostreatus) as antimicrobial and natural antioxidant. Biofarmasi J. Nat. Prod. Biochem. 2019, 17, 14-20. [CrossRef]

73. Sathyan, A.; Abdul Majeed, K.; Majitha, V.K.; Rajeswary, K.R. A Comparative study of antioxidant and antimicrobial activities of Pleurotus ostreatus, Pleurotus eryngii and Pleurotus djamor. Int. J. Agric. Innov. Res. 2017, 5, 907-912.

74. Adebayo, E.A.; Martínez-Carrera, D.; Morales, P.; Sobal, M.; Escudero, H.; Meneses, M.E.; Avila-Nava, A.; Castillo, I.; Bonilla, M. Comparative study of antioxidant and antibacterial properties of the edible mushrooms Pleurotus levis, P. ostreatus, P. pulmonarius and P. tuber-regium. Int. J. Food Sci. Technol. 2018, 53, 1316-1330. [CrossRef]

75. Pandey, A.T.; Pandey, I.; Kerkar, P.; Singh, M.P. Antimicrobial activity and mycochemical profile of methanol extract from Pleurotus flabellatus. Vegetos 2021, 34, 619-629. [CrossRef]

76. Ngai, P.H.; Ng, T.B. A hemolysin from the mushroom Pleurotus eryngii. Appl. Microbiol. Biotechnol. 2006, 72, 1185-1191. [CrossRef]

77. Alam, N.; Amin, R.; Khan, A.; Ara, I.; Shim, M.J.; Lee, M.W.; Lee, U.Y.; Lee, T.S. Comparative effects of oyster mushrooms on lipid profile, liver and kidney function in hypercholesterolemic rats. Mycobiology 2009, 37, 37-42. [CrossRef]

78. Inetianbor, J.E.; Yakubu, J.M.; Ezeonu, S.C. Effects of food additives and preservatives on man-A review. Asian J. Sci. Technol 2015, $6,1118-1135$.

79. Branen, A.L.; Haggerty, R.J. Introduction to food additive. In Food Additives, 2nd ed.; Branen, A.L., Davidson, P.M., Salminen, S., Thorngate, J.H., III, Eds.; Mercel Dekker: New York, NY, USA, 1999; pp. 1-10.

80. Xiong, Y.L. Nonmeat ingredients and additives. In Handbook of Meat and Meat Process, 2nd ed.; Hui, Y.H., Ed.; CRC Press: Boca Raton, FL, USA, 2012; pp. 573-588. [CrossRef]

81. Fernández, J.; Pérez-Álvarez, J.A.; Fernández-López, J.A. Thiobarbituric acid test for monitoring lipid oxidation in meat. Food Chem. 1997, 59, 345-353. [CrossRef] 
82. Schill, S.; Stessl, B.; Meier, N.; Tichy, A.; Wagner, M.; Ludewig, M. Microbiological safety and sensory quality of cultivated mushrooms (Pleurotus eryngii, Pleurotus ostreatus and Lentinula edodes) at Retail Level and Post-Retail Storage. Foods 2021, 10, 816. [CrossRef] [PubMed]

83. Ravishankar, S.; Pandey, M.; Tewari, R.P.; Krishna, V. (Development of sporeless/low sporing strains of Pleurotus through mutation. World J. Microbiol. Biotechnol. 2006, 22, 1021-1025. [CrossRef]

84. Stephan, A.; Ahlborn, J.; Zajul, M.; Zorn, H. Edible mushroom mycelia of Pleurotus sapidus as novel protein sources in a vegan boiled sausage analog system: Functionality and sensory tests in comparison to commercial proteins and meat sausages. Eur. Food Res. Technol. 2018, 244, 913-924. [CrossRef]

85. Ishak, W.; Rosli, W.; Solihah, M.A.; Aishah, M.; Fakurudin, N.A.; Mohsin, S.S.J. Colour, textural properties, cooking characteristics and fibre content of chicken patty added with oyster mushroom (Pleurotus sajor-caju). Int. Food Res. J. 2011, 18, 612-618.

86. Wan Ishak, W.R.; Solihah, M.A. Nutritional composition and sensory properties of oyster mushroom-based patties packed with biodegradable packaging. Sains Malays. 2014, 43, 65-71.

87. Wan-Mohtar, W.A.A.Q.I.; Halim-Lim, S.A.; Kamarudin, N.Z.; Rukayadi, Y.; Rahim, M.H.A.; Jamaludin, A.A.; Ilham, Z. Fruitingbody-base flour from an Oyster mushroom waste in the development of antioxidative chicken patty. J. Food Sci. 2020, 85, 3124-3133. [CrossRef]

88. Wan Rosli, W.I.; Solihah, M.A.; Mohsin, S.S.J. On the ability of oyster mushroom (Pleurotus sajor-caju) confering changes in proximate composition and sensory evaluation of chicken patty. Int. Food Res. J. 2011, 18, 1463-1469.

89. Wan Rosli, W.I.; Solihah, M.A.; Fakurudin, N.A.N.; Aishah, M.S.; Mohsin, S.S.J. The effect of Pleurotus sajor-caju (PSC) addition on the nutritional composition and sensory properties of poultry-based patty. Int. J. Nutr. Food Eng. 2011, 5, 749-752.

90. Husain, H.; Faujan, N.H. Potential application of grey oyster mushroom stems as Halal meat replacer in imitation chicken nuggets. Food Res. 2020, 4, 179-186. [CrossRef]

91. Yahya, F.; Ting, H.T. Effect of different ratios of chicken meat to fresh osyter mushroom (Pleurotus sajor-caju) on the physicochemical properties and sensory acceptability of sausages. Int. J. Food Agric. Nat. Resour. 2020, 1, 7-14. [CrossRef]

92. Lu, F.; Chen, Y.; He, C.; Li, J.; Li, B. Sensory evaluation and textural properties of mushroom sausages. Adv. J. Food Sci. Technol. 2014, 6, 792-796. [CrossRef]

93. Wan Rosli, W.I.; Maihiza, M.S.; Raushan, M. The ability of oyster mushroom in improving nutritional composition, $\beta$-glucan and textural properties of chicken frankfurter. Int. Food Res. J. 2015, 22, 311-317.

94. Prisilia, F.H.; Praptinngsih, Y.; Fauziah, R.R. Karakteristik sosis berbahan baku campuran jamur tiram putih (Pleurotus ostreatus) dan otak sapi. J. Agroteknologi. 2018, 11, 117-127. [CrossRef]

95. Dosh, K.S.; Tawfiq, N.N.; Mohammed, S.O. Effect of partial replacement of beef meat with powdered of oyster mushroom Pleurotus eryngii (King oyster mushroom) on physical and sensory properties of meat burger. Iraq J. Mark. Res. Consum. Prot. 2015, $7,388-400$

96. Cerón-Guevara, M.I.; Rangel-Vargas, E.; Lorenzo, J.M.; Bermúdez, R.; Pateiro, M.; Rodríguez, J.A.; Sánchez-Ortega, I.; Santos, E.M. Reduction of salt and fat in frankfurter sausages by addition of agaricus bisporus and pleurotus ostreatus flour. Foods $\mathbf{2 0 2 0}$ 9, 760. [CrossRef]

97. Wan Rosli, W.I.; Solihah, M. Effect on the addition of Pleurotus sajor-caju (PSC) on physical and sensorial properties of beef patty Int. Food Res. J. 2012, 19, 993-999.

98. Tabaldo-Tucar, M.; Solar, M.N.J.B. Choose your patty: The sensory characterization and consumer acceptance of burger patties with oyster mushroom (Pleurotus ostreatus) enrichment. J. Phys. Conf. Ser. 2019, 1254, 012017. [CrossRef]

99. Wan Rosli, W.I.; Solihah, M.A. Nutritive qualities of patties prepared with mixture of meat and oyster mushroom. Int. Food Res. J. 2014, 21, 2001-2006.

100. Wang, L.; Li, C.; Ren, L.; Guo, H.; Li, Y. Production of Pork Sausages Using Pleaurotus eryngii with Different Treatments as Replacements for Pork Back Fat. J. Food Sci. 2019, 84, 3091-3098. [CrossRef]

101. Rabou, E. The effect of substitution oyster mushroom on chemical composition and quality attributes of meatballs. J. Food Dairy Sci. 2016, 7, 391-398. [CrossRef]

102. Komariah; Ulupi, N.; Hendrarti, E.N. Sifat Fisik Bakso Daging Sapi Dengan Jamur Tiram Putih (Pleurotus ostreatus) Sebagai Campuran Bahan Dasar. J. Indones. Trop. Anim. Agric. 2005, 30, 34-41.

103. Lamadjido, S.R.; Umrah, U.; Jamaluddin, J. Formulasi dan analisis nilai gizi bakso kotak dari jamur tiram putih (Pleurotus ostreatus). Galen. J. Pharm. 2019, 5, 166-174. [CrossRef]

104. Falahudin, A. Kajian Kekenyalan dan Kandungan Protein Bakso Menggunakan Campuran Daging Sapi Dengan Tepung Jamur Tiram Putih (Pleurotus ostreatus). J. Ilmu Pertan. Peternak. 2013, 1, 1-9.

105. Özünlü, O.; Ergezer, H. Possibilities of using dried oyster mushroom (Pleurotus ostreatus) in the production of beef salami. J. Food Process. Preserv. 2021, 45, e15117. [CrossRef]

106. Qing, Z.; Cheng, J.; Wang, X.; Tang, D.; Liu, X.; Zhu, M. The effects of four edible mushrooms (Volvariella volvacea, Hypsizygus marmoreus, Pleurotus ostreatus and Agaricus bisporus) on physicochemical properties of beef paste. LWT 2021, 135, 110063. [CrossRef]

107. Aritonang, S.N.; Allismawita, A.; Dahlia, S.N. The effect of white oyster mushroom (pleurotus ostreatus) addubg on the quality of unproductive quail (Coturnixcoturnix japonica) abon shredded meat. Int. J. Food Sci. Agric. 2019, 3, 232-236. [CrossRef] 